\title{
Exploring the Common Technology Adoption Enablers among Malaysian SMEs: Qualitative Findings
}

\author{
Nor Hazana Abdullah ${ }^{1}$, Eta Wahab ${ }^{1} \&$ Alina Shamsuddin ${ }^{1}$ \\ ${ }^{1}$ Faculty of Technology Management and Business, Universiti Tun Hussein Onn Malaysia, Malaysia \\ Correspondence: Nor Hazana Abdullah, Faculty of Technology Management and Business, Universiti Tun \\ Hussein Onn Malaysia, Malaysia. Tel: 6-013-715-1236. E-mail: hazana@uthm.edu.my
}

Received: December 13, 2012

Accepted: July 2, $2013 \quad$ Online Published: November 18, 2013

doi:10.5539/jms.v3n4p78

URL: http://dx.doi.org/10.5539/jms.v3n4p78

\begin{abstract}
Technology has been recognized as one of strategic resources for sustaining competitiveness among firms regardless of their sizes. Challenges in globalizations and strategic alliances are some of the issues underpinning technology adoption among SMEs. However, existing models on technology adoption have not provided sufficient insights on factors that could influence the successful adoption of technology among SMEs in Malaysia. Varying levels of technology adoption and high industrial diversity hinder comprehensive understanding on common factors affecting technology adoption. Therefore, this study aims to identify significant enablers that could have pervasive influence on technology adoption among SMEs in Malaysia by integrating internal and external factors together with the SME unique characteristics. A preliminary study via in-depth interviews was conducted to propose the SME technology adoption model to validate the influence of external factors, internal factors and SMEs' owner-manager characteristics. This study employed multiple case studies strategy as its research design and in-depth interviews as primary data collection method. Collected data were analyzed using thematic analyses to identify recurring factors across cases. The findings showed that notwithstanding of the technologies adopted by the firms, internal factors and SME's owner-managers characteristics have significant influence on technology adoption among SMEs.
\end{abstract}

Keywords: technology adoption, owner-managers' characteristics, Malaysian SMEs

\section{Introduction}

Technology has been recognized as competitive resources and strategies to maintain organizational effectiveness. Organizational ability to adopt technology would render its competitiveness and sustainability in today's dynamic business environment. This is particularly relevant to small and medium enterprises (SMEs) as the use of technology would enable them to compete with their larger counterparts. Tidd and Bessant (2009) further claimed that successful SMEs are those who innovate by adopting technologies that give them a market competitive edge. SMEs that innovate show growth and sustainable performance compared to those whose not (Tidd \& Bessant, 2009). Despite concerted efforts by the government to promote technology adoption among SMEs in Malaysia (Abdullah \& Shamsuddin, 2010), there is no clear indicator of its success. For example, a study done in 1988 on technology adoption among SMEs found low level of technology adoption (Saskatchewan National Research Council, 1988). Similarly, recent studies on specific technologies such ICT, internet and e-commerce (e.g., Alam \& Ahsan, 2007; Alam et al., 2007; Hashim, 2007) also showed low adoption. Furthermore, in terms of R\&D activities, SMEs are still lagging behind (Eight Malaysian Plan, 2001-2005). Different categorization of technologies across industries has set hurdles to researchers who would like to study technology adoption at macro a.k.a national level.

Since adoption of technology is complex processes which are affected by multiple factors, identification of the factors that significantly affect technology adoption would provide insight on how to increase technology adoption among SMEs. This is a particularly significant issue since SMEs have been recognized as the economic impetus in both developed and developing countries (e.g., La Rovere, 1998; Normah, 2006). Furthermore, limited studies on technology adoption among SMEs especially in the context of Malaysia have caused the chasm of knowledge on SMEs' technology adoption issues.

This paper is divided into five sections. Section (i) is the introduction-describing the overall overview of the importance of SMEs, section (ii) is on theories related to technology adoption and related works concerning 
technology adoption among SMEs, section (iii) is on the methodology, section (iv) is on discussions and section (v) is the conclusions.

\section{Overview on Technology Adoption Theories}

Adoption refers to the stage in which technology is selected for use by an individual or organization. Consequently, theories or models on technology adoption tend to cluster around individual and organizational levels. However, at the individual level, technology adoption is commonly referred to as technology acceptance.

Technology Acceptance Model (TAM) by Davis (1989) is one of the most frequently cited, researched on and tested since it was introduced in 1986. Emerged from the Theory of Reasoned Action (Fishbein \& Ajzen, 1975), this theory postulates that acceptance of technology by individuals would depend on the technology perceived usefulness (PU) and Perceived Ease of Use (PEOU). Venkatesh and Davis (1996) had further revised TAM by excluding attitude towards use from the model as it is claimed not to fully mediate the relationship between PEOU and PU with intention to use (Brown et al., 2002). Consequently, the revised TAM (without the attitude construct) has received substantial empirical support from various studies (for example, Brown et al., 2002; Venkatesh, 2000, Venkatesh \& Davis, 1996). In 2000, another version of TAM called TAM II was introduced. TAM II defined social influence and cognitive instruments as determinants of PU while anchor and adjustments are determinants of PEOU (Venkatesh \& Morris, 2000). Venkatesh et al. (2003) further introduced a modified version of TAM which is called Unified Theory of Acceptance and Use of Technology or UTAUT. This model suggested that performance expectancy, effort expectancy, social influence, and facilitating conditions are direct determinants of usage intention and behavior (Venkatesh et al., 2003). Gender, age, experience, and voluntariness of use are mediators between the relationship of four key constructs and usage intention and behavior (Venkatesh et al., 2003).

TAM model have been used extensively in the field of information system, specifically with regard to IT adoption for a comprehensive review, refer to Lee, et al. (2003). Proliferation of IT-based studies using TAM models have witnessed numerous attempts to enhance the model by adding antecedents (e.g., Qi et al., 2006), mediating (e.g., Wang \& Qualls, 2007) and moderating (e.g., Featherman \& Muller, 2003) variables to improve the model's robustness. However, very limited studies have been done with regards to other types of technologies especially in forms of production or strategic technologies. In fact, a recent research agenda on technology adoption among SMEs in Malaysia proposed by a group of researchers in Malaysia also focuses on information technology (Ramayah et al., 2009).

Other than TAM, Theory of Planned Behavior (TPB) is another adapted version of TRA. TPB posits that individual behavior is driven by behavioral intentions. An individual's attitude toward the behavior, the subjective norms surrounding the performance of the behavior, and the individual's perception of the ease with which the behavior can be performed (behavioral control) are the direct determinants of the behavioral intentions. Unlike TAM, TPB has received less attention among researchers since TAM is claimed to be more robust and simple to use (Iqbaria et al., 1997).

Both the original theories of TAM and TPB focused on behavioral aspects of technology adoption while Roger's Innovation Diffusion theory focuses on the process by which an innovation is communicated (Rogers, 1995). Rogers (1995) classified individuals based on how quickly their adoption of innovation occurs. He depicted a bell-shaped distribution curve of innovation and potential for acceptance that shows innovator $(2.5 \%)$, early $(13.5 \%)$, early majority (34\%), late majority (34\%), and laggard (16\%) adopters. Innovators are identified as appreciative of new ideas, and they are usually at the forefront. Early adopters are usually the first to adopt an innovation after the innovators. Early majority adopters are viewed as average persons within a system who adopt new ideas once the early adopters do so. Late majority adopters are skeptical and often adopt new ideas after the average person within an organization. Laggard adopters are the last to adopt innovation in a social system (Rogers, 1995). The diffusion of innovation theory states that adoption phases going through a gradual growth, followed by a dramatic growth, gradual stabilization, and - finally - decline.

A framework of innovation adoption by Tornotzky and Fleischer (1990) departs from all the above theories by focusing on integration of three contexts which are technological contexts, organizational contexts and environmental contexts. The technology-organization-environment (TOE) framework postulates that these contexts influence the process which innovations are adopted and implemented in organizations. Although the framework is not enormously popular, it has received some empirical support (e.g., Chau \& Tam, 1997; Kuan \& Chau, 2001). Nonetheless, this theory fails to consider the unique characteristics of SMEs and the importance of people aspects. 
A review of these theories indicates the presence of various factors affecting technology adoption. Some of the factors are more salient that others in terms for their recurrence in various models. However, much emphasis has been put on the individual technology adoption via TAM model and its derivatives. Although Roger's model and TOE framework provide a basis for organizational technology adoption theory, their usage might be limited to large organization since unique characteristics of SMEs have not be accounted for in the models. As for TAM, although there is an effort to adapt the model for organizational analysis, the effort is quite fragmented in nature. This indicates a significant gap in terms of theory development of organizational technology adoption especially in context of SMEs.

Perhaps the resource-based view theory is more relevant as the basic premise of this study is that the successful integration of technology, organization and people would drive organizational performance. Adoption of the right technology by the organizations and the human resource would increase organizational effectiveness. This theory, which is advocated by Hamel and Prahalad in their book "Competing for the Future" (1994), conceptualizes an organization as a bundle of resources. It is these resources, and the way that they are integrated, that make organizations different from one another and in turn allow them to deliver products and services in the market. SMEs, in order to remain competitive and sustainable, need to adopt relevant technologies and create infrastructures and mobilize human resources around the technologies.

Another theory that might shed some lights is the Upper Echelon Theory by Hambrick and Mason (1984). According to this theory, SMEs are significantly influenced by their owner-managers who play significant part in the establishment, development and advancement of the organization (Taalika, 2004). This theory also suggests that the more complex a decision is, such as pertaining to adoption of technology, the more important the personal characteristics of the decision makers such as their age and level of education. This theory has received some empirical support. This contention is further supported by the work of Petroni and Rizzi (2001) who claimed that technology adoption is based three stages of cognitive, affective and behavior. They claimed that at the cognitive stage, SMEs' owner-managers become aware of the technology and through analysis of benefits and feasibility, they develop feelings towards it. If the feeling is favorable, the firm will move to behavioral stage in terms of actual adoption of technology which is translated into organizational willingness (Petroni \& Rizzi, 2001). Based on this premise, they postulated four constructs which are awareness, analysis of benefits, feasibility and organizational willingness. However, it should be recognized that the technology adoption at organizational level is a 'process' that intricately connected with various determinants. It is hypothesized that the success of any technology adoption will depend on various factors such as technology characteristics, organizational characteristics and external factors.

\subsection{Determinants of Technology Adoption for SMEs}

The unique nature of small and medium enterprises (SMEs) has proved to be an importance consideration for any research interest. According to Wilson and Bates (2003), managing a small business requires a different approach as from managing a big or multinational corporation due to their unique characteristics. Although there is no universally accepted characteristics or features of small business or SMEs, Bridge et al. (2003) and Wong and Aspinwall (2004) identified several common characteristics of small business which include ownership, resource, informal systems and procedures, control, management, organization structure, and organizational culture.

In Malaysia, small business is usually privately owned by individual or partners, typically registered as sole proprietorship, partnership or private limited company where the management of the business resides with the owners (Hashim, 2000). The entrepreneur or founder of the business directs the company, and acts as both manager and worker, leading to the term owner-managers (Ikävalko, 2008). A small business often has limited resources compared with larger firms (O'Regan, MSims, \& Ghobadian, 2005) and more vulnerable to changes in the external environment (Wilson \& Bates, 2003). Thus, they are highly dependent on the ability of the owner-managers to generate resources and manage business risks (Bridge et al., 2003). The structure of small business is often flat and informal (Supyuenyong, Islam, \& Kulkarni, 2009) which leads to greater flexibility in work but with limited or less clear division of responsibilities. The owner has to do almost everything and the workers are normally expected to be able to function as generalists since there is no clear demarcation of tasks. The operations are also less complex where processes are more fluid and adaptable to various situations (Wong \& Aspinwall, 2004). Since most small businesses started up with just a few employees and narrow scope of operations, systems and procedures tend to be informal until the SMEs' owner-managers introduce more formal systems for running the business (Bridge et al., 2003). The strategy of business will also correspond to that of the SMEs' owner-managers due to their dominant position (Bridge et al., 2003). 
In terms of organizational culture, SMEs usually have an informal, organic and unified culture. The behaviour of employees is more easily influenced by the owner-managers' philosophy and beliefs (Schein, 1991; Supyuenyong et al., 2009). According to Schein (1991), leadership of SMEs' owner-managers is critical to the birth and maintenance of organizational culture. He stated that during the formation of organizations and its early life, leaders or founders dictate organizational culture through resolving the "external adaptation and internal integration problems". Since founders or leaders are usually entrepreneurs who inhibit high level of self-confidence and determination, they impose strong assumptions to their founding organizations. When these assumptions survive and are successful in the business environment, they are perceived as correct and across time, they are internalized as part of the organizational culture. The SMEs' owner-managers create mechanisms for the embedding and reinforcement of the culture. Cultural norms form around the focus of the SMEs' owner-managers' attention, such as reactions to crises, role modelling and recruitment strategies.

As evident from the discussion on the characteristics of small business, the owner-managers not only play major roles in the organization but they are indeed the 'heart' and the 'brain' of the organization. They have significant influence on the decision-making processes (O'Regan et al., 2005), product innovation (Matzler et al., 2008), and knowledge management initiatives (Supyuenyong et al., 2009). Therefore, it is not surprising to find that their roles have received much interest in SMEs and entrepreneurship literatures (O'Regan et al., 2005). They play significant part in the establishment, development and advancement of the organization (Taalika, 2004). Therefore, any major decisions regarding technology adoption would reside on the SMEs' owner-managers. This contention is further supported by the work of Petroni and Rizzi (2001) who claimed that technology adoption is based three stages of cognitive, affective and behavior. They claimed that at the cognitive stage, SMEs' owner-managers become aware of the technology and through analysis of benefits and feasibility, they develop feelings towards it. If the feeling is favorable, the firm will move to behavioral stage in terms of actual adoption of technology which is translated into organizational willingness (Petroni \& Rizzi, 2001). Based on this premise, they postulated four constructs which are awareness, analysis of benefits, feasibility and organizational willingness. However, it should be recognized that the technology adoption at organizational level is a 'process' that intricately connected with various determinants. It is hypothesized that the success of any technology adoption will depend on various factors such as technology characteristics, organizational characteristics and external factors.

\subsubsection{SMEs' Owner-Managers' Characteristics}

Leaders play pivotal roles in primary adoption decision in organizations and in almost the whole spectrum of adoption process (Beatty et al., 2001). Their commitment, both in terms of resources and change in the adoption process is imperative (Dong, 2001). Wu et al. (2006) asserted that leadership refers to not only the top leaders' inclination to adopt technology but also the ability to formulate, implement, and regulate technology strategy. A study in 1995 suggested two main classes of variables that are important in determining adoption of an innovation: individual characteristics and organizational characteristics (Thong \& Yap, 1995). Three CEO characteristics are studied which includes CEO innovativeness, CEO attitude towards adoption of IT, and CEO IT knowledge. Three organizational characteristics studied are business size, competitiveness of environment, and information intensity. The results suggest CEO characteristics are important factors affecting IT adoption in small businesses regardless of their sizes. Small businesses are more likely to adopt IT when the CEOs are more innovative, have a positive attitude towards adoption of IT, and possess greater IT knowledge. A study by Hashim (2007) found that the characteristics of SMEs owners are significant predictor of SMEs' technology adoption through a survey of 383 SMEs. The ICT adoption among SMEs' owners is not only lower than expected but the ICT skills possessed by the SME owners are poor, and their use of ICT is slow and late. This finding indicates that SMEs owners' characteristics have significant influence on the ICT adoption. This might be contributed to the fact in SMEs' the owner dictates the direction of the firm. SMEs owners that have poor ICT skills might not so incline to adopt ICT and thus perceived IT adoption as difficult.

\subsubsection{Organizational Characteristics}

Managers make decision to adopt technology within an organizational context (Nystrom et al., 2002). Successful adoption occurs when organizational infrastructures and resources are directed towards sustaining the adoption effort. According to Khalil (2002), technology strategy, organization structure, technology culture and people are among assessment areas critical to successful technology adoption. Tarafdar and Vaidya (2006) substantiate Khalil's contention and found that organizational culture and structure significantly affect adoption of e-commerce technologies in India. Kuan and Chau (2001) found both perceived financial cost and perceived technical competences significantly differentiate adopters and non adopters of electronic data interchange (EDI). Wang and Qualls (2007) proposed organizational technology climate which include level of technocratization, 
management support and technology budget as imperative in technology adoption of hospitality-related technologies.

\subsubsection{External Factors}

It is found that a firm's ability to efficiently adopt high technology involves an assessment of internal factors such as strategy and human organization and external factors like government support and relationships (Khalil, 2002). Moreover, it is argued that as the sophistication of technology increases, the need for such external support increases. Several studies have reported that the external environment have an effect on the intention to adopt (see Iacovou, 1995; Tarafdar, 2006). They mainly argue that when a company is facing keen market competition, adoption of technology is imperative to maintain or enhance its competitiveness. Furthermore, small businesses are usually characterized by a high level of environmental uncertainty, which necessitate scrutinizing of external factors. Khalil (2002) claimed that competitors and markets are important assessment areas for technology positioning. Gradon and Pearson (2004) found that external pressure which includes competition, social factors, and dependency of other firms using e-commerce, industry and government as significant determinant of e-commerce adoption. Similarly, Tung and Reick (2005) examined 128 companies in Singapore and found that external pressure and social influence are significantly related to the adoption of e-government services. Zhang and Dhaliwal (2009) focused on effect of partner dependence and competition intensity on adoption of supply chain management technology. Consistent with previous studies, they found that significant effect of external factors. However, contrary to above studies, Nikas et al. (2007) found external competitive pressures in forms of partner's adoption of collaborative systems and the improvement of company's responsiveness to their customers as insignificant.

Review of all the various literatures indicates a wide spectrum of determinants for technology adoptions. Thus, it is necessary to delineate factors that have the most significant effects especially in the context of SMEs. As this paper aimed to identify common, but most significant determinants of technology adoption across industries, further exploration is warranted.

\section{Methodology}

\subsection{Research Design}

Multiple case studies design was used to explore the factors that would significantly influence technology adoption among SMEs. This research strategy was advocated due to the exploratory nature of this study (Yin, 2010). Furthermore, this study would like to capture the 'rich' and 'full' accounts of technology adoption determinants of sampled cases so that the dynamic interaction among them could be further investigated and understood.

\subsection{Selection of Participants}

Six cases (SMEs) were selected using purposive sampling. According to Merriam (2001), purposeful sampling is based on the assumption that the investigator wants to discover, understand and gain insight about the issue in hand and therefore must select a sample from the most can be learned. Therefore, purposive sampling was used in this study to identify the sample of persons with known or demonstrable experience and expertise in the technology adoption in the companies. Based on this argument, the persons appointed by the SMEs' owner-managers to participate in our interviews were perceived as the most appropriate candidates as the SMEs' owner-managers had been informed about the objective of the study.

Since there is no rule of thumb for adequate number of sample for qualitative studies (Yin, 2001), these six cases were considered sufficient to provide insight on issues being studies. A principle selection criterion for cases is SMEs that used technologies for production of their products or services. Technology in the context of this study refers to 'all knowledge, products, processes, tools, methods and system employed in the creation of goods or in providing services' (Khalil, 2002). Thus, no specific technology is focused on and intentional selection of six companies from completely different industries was done as one of the key objectives of this study is to identify common enabler of technology adoption across industries and technologies used.

\subsection{Data Collection and Analysis}

Primary data collection method was through in- depth interviews. In-depth interview method was used because this approach allows for interviewer probing and clarification on interviewee's answers (Kvale, 1996). Each interview and the questions used were designed to discover the enablers of technology adoption, their interactions and relative importance. The interviews were done at the respective companies and thus physical observations of the companies' setting, layout were done simultaneously. This observation was considered reflective of what being said during the interviews and verification of interviewees' explanation. Nonetheless, 
observation of this nature was not included as part of the research methodology since no official permission was obtained. Interview durations varied, with a mean of 90 minutes per interview with Bahasa Malaysia and English as main languages used. Interviews were done based on the interviewees' agreement to participate. The interviews were tape recorded and transcribed verbatim.

The interview data were transcribed and later on subjected to data analysis following Miles and Huberman's suggestion which are (i) data reduction, (ii) data display and (iii) draw conclusions. As a first step, the researcher reviewed the data to identify relevant parts. The researcher then developed primary categories by marking all the relevant parts and linking them into significant socio-psychological themes (Philaretou \& Allen, 2006). The data were then fitted into the categories. Descriptive paragraphs about the categories were written, and relationships between the categories were explored (Ausband, 2006; Hipsky, 2006; Morse \& Field, 1995; Philaretou \& Allen, 2006; Polit \& Beck, 2004). Pairwise comparisons between categories and responses from the participants were done to ensure that the "voice" of the participant was included and that data saturation was achieved (Onwuegbuzie \& Leech, 2007). When categories were linked, the researcher went back to the original data to search for any missing data to ensure that all information was analyzed. Secondary data in forms of company profiles were accessed through the company websites.

\subsection{Ethical Considerations}

Before data collection, written consent explaining the aims and nature of the study was given to the participant. Also, the researcher informed the participant there was no risk in participation of the study. He was informed of refusing to participate at any time of the study, by not attending the interview. This also guaranteed anonymity (Polit \& Beck, 2004). Since the context of the setting did not require third-party approval, only one written consent form from the researcher was obtained. To protect personal data of the participant, he was assured that his information was only exposed to the researcher, and his personal information would not be given to any third parties. Also, the information would be destroyed after the study. Contact phone number and email address of the researcher were given to the participant, and he was welcome to contact the researcher if he had a question. The participant joined the study voluntarily. The participant agreed to join the study by signing the consent letter prepared by the researcher.

\subsection{Trustworthiness}

Credibility and transferability were guaranteed to maintain trustworthiness in qualitative study (Polit \& Beck, 2004; Morse \& Field, 1995; Yin, 1994). To maintain credibility, the researcher had persistent observation on the repeated characteristics that were relevant to phenomena (Polit \& Beck, 2004). The researchers were experienced practitioners and researchers in qualitative study. The researchers could self-critique, and obtain feedback from the team, then make changes accordingly throughout the study (Ausband, 2006).

As the interview was the unique data collection method in the study, it had the risk of including incorrect data analysis and researcher bias in analysis and reporting (Yin et al., 1994). To prevent this, preliminary data summaries were reviewed and discussed among research team members (Polit \& Beck, 2004; Yin, 1994).

\section{Findings}

\subsection{Introduction}

During the data analysis, the research questions focused on the patterns of action and behavior (the 'what') in order to understand the process(es) (the 'how') that influence the technology adoption. Several themes common to all interviewees emerged from the analysis of interview data. In-depth explanation on how various enablers of technology adoption interact was conducted to answer research question. Interviews were conducted with six companies' representatives who held various positions in the companies. These representatives were appointed by the SMEs' owner-managers themselves as the valid sources of reference. The qualitative data analysis section begins with background and demographic information on of the SMEs. Next, an analysis of the interview data is presented and summary of the findings is provided.

\subsection{Research Background}

The major findings of this study are based on the qualitative evidence gathered in the context of Malaysian SMEs. Thus, generalization of the findings might be limited although their rich information should compensate it. In essence, all the participating companies used various technologies for their business. 
Table 1. Participating companies backgound

\begin{tabular}{|c|c|c|c|c|c|}
\hline Company & $\begin{array}{l}\text { Year } \\
\text { Established }\end{array}$ & $\begin{array}{l}\text { No of } \\
\text { Employees }\end{array}$ & Type of Business & Technologies & $\begin{array}{l}\text { SME } \\
\text { Classification }\end{array}$ \\
\hline A & 1992 & 120 & $\begin{array}{l}\text { High-technology valves and } \\
\text { green cabin construction }\end{array}$ & $\begin{array}{l}\text { Advanced Engineering } \\
\text { Simulation Software }\end{array}$ & $\begin{array}{l}\text { Mixed Performing } \\
\text { SME }\end{array}$ \\
\hline B & 2007 & 17 & $\begin{array}{l}\text { Manufacture medical device } \\
\text { for synthetic bone graft } \\
\text { material }\end{array}$ & $\begin{array}{l}\text { Advanced } \\
\text { biotechnology processes }\end{array}$ & $\begin{array}{l}\text { Mixed Performing } \\
\text { SME }\end{array}$ \\
\hline $\mathrm{C}$ & 1984 & 100 & $\begin{array}{l}\text { Manufacture recycled } \\
\text { ferrious metal and paper } \\
\text { scrap and plastic resin }\end{array}$ & $\begin{array}{l}\text { Green Recycling } \\
\text { methods-self-develop }\end{array}$ & $\begin{array}{l}\text { Innovative certified } \\
\text { company }\end{array}$ \\
\hline $\mathrm{D}$ & 1991 & 110 & $\begin{array}{l}\text { Production of } \\
\text { oxo-biodegradable plastic } \\
\text { bags }\end{array}$ & $\begin{array}{l}\text { Green Recycling } \\
\text { methods-self-develop }\end{array}$ & $\begin{array}{l}\text { Innovative certified } \\
\text { company }\end{array}$ \\
\hline $\mathrm{E}$ & 1985 & 72 & $\begin{array}{l}\text { Manufacturer of Palm Oil } \\
\text { Machineries }\end{array}$ & $\begin{array}{l}\text { Design and manufacture } \\
\text { pal oil machineries }\end{array}$ & $\begin{array}{l}\text { High Performing } \\
\text { SME }\end{array}$ \\
\hline $\mathrm{F}$ & 1992 & 130 & $\begin{array}{l}\text { Specializes in precision } \\
\text { injection moulded } \\
\text { components }\end{array}$ & $\begin{array}{l}\text { Design and manufacture } \\
\text { plastic components }\end{array}$ & $\begin{array}{l}\text { High Performing } \\
\text { SME }\end{array}$ \\
\hline
\end{tabular}

\subsection{SMEs' Owner-Managers' Characteristics}

To aid clarity and highlight the emergence of themes on enablers of technology adoption among cases, the discussion of owner-managers characteristics is further delineated into several sub sections as follows;

\subsubsection{Age, Qualifications, Experience and Personal Characteristics}

All owner-managers interviewed were males that had at least college degrees, varying from engineering degrees to degree in Psychology except for owner of Company E, who had only Diploma degree. The owner-manager of Company C had MBA aside from the first degree. Their ages ranged from 36 years old to late 40s. Two of the owner-managers were Malays while the others were Chinese. All the owner-managers are active directors and involved directly in daily operations of the companies. All of them had vast experiences, locally and internationally, which was directly related to the business they were currently involved in. Most of these experiences were derived from their previous employments. Vast experiences and industrial exposure are the key characteristics of these owner-managers. For example, an excerpt from Company's E;

He understands from A to $Z$, as he works from the bottom before he owned this company. Each machine, from the smallest screw, he can assemble them all.

Further,

He is visionary, open and broad minded since our market is international. Papua New Huines, Nigeria, Thailand, Indonesia. He inspires... all works must be on time. We need to learn how to work efficiently...like ISO.

All the SMEs' owner-managers were strategic thinkers, passionate, visionary and risk takers. Their exemplary behaviors gained trust and reverence among their employees, evident from the interviews done with their employees. They were willing to go against current industrial status quo and experimenting with different business strategies. They constantly strive to learn new knowledge and scan new technologies which were beneficial to their business.

For example, Company $\mathrm{F}$ had its vision and mission formally written and displayed on the notice boards and in offices. When asked about who was responsible to form the vision and mission, she said

MD will come out with the vision.... maybe five or six years later, it will be revised and come out with the new vision.

Based on the company's mission, departments' objectives were formed;

Every month, we have one management meeting. At that time all head of departments will join in and send the objectives whether we achieve the targets or not. If reach, you want to move to another objectives or if cannot reach, so what is the action to take.

In company $\mathrm{C}$; 
We have mission, vision. We do for our value not for money. We are valuing for life. Each material deserves second chance. We give ourselves second chance too.

Furthermore,

The technologies were brought here by owner. He learned that from everywhere. From his daily life, from universities, expertise, when travelling, head hunting people. He learned from consultant for 3 years. Learning from local people, oversea people. They share what they have. He does usually go somewhere else with his workers. He is a very hardworking person.

Clearly, all companies had clear mission dictated by their respective owner-managers that steer the companies to the right direction.

\subsubsection{Technology Know-How}

All owner-managers had high level of technology know-how. Therefore, they were involved throughout the technology assessment, selection and acquisition process and were the primary decision maker in final technology adoption process. Their decision on which technology to adopt was significantly influenced by the owner's experience, knowledge and exposure. For example, owner-manager of Company $\mathrm{C}$ would visit the techno-based exhibitions all over the world to enhance his knowledge of certain technologies. If they lack technology know-how with regard to certain new technology, they would collaborate with universities and government bodies such as Malaysian Technology Development Corporation (MTDC). In fact, two of the companies have their own R\&D teams for continuous innovation efforts. For all these companies, they believe that the technologies that they had need to be continuously improved to sustain their competitiveness.

International collaborations differentiate Company $\mathrm{C}$ and $\mathrm{D}$ from others. As both of them formed their own R\&D teams, they collaborated with international bodies for new technologies and expertise. For example, Company C employed an expatriate scientist from Netherland to lead his R\&D team while Company D collaborated with a well-known China's research institute called Fuchoo Science Polymer Institute.

Their abilities to comprehend various aspects of technologies being used to drive organizational performance could be regarded as exemplary. For example, Company C;

\section{The boss innovate. He will think how to fit the technologies in the company}

Benefits of the technology were key selection criteria, especially in terms of long term business sustainability. For example, owner-manager of Company A claimed that the use of the engineering simulation software stimulate company's growth and profit by $30 \%$. All the companies agreed that technologies being used contribute significantly to their productivity, performance and profit.

\subsubsection{Organizational Characteristics}

Since the size of these companies was small, the organizational structure remains organic with a few cross functional teams. For example, Company A had two main operation divisions; valves and cabin. Under these two divisions, there were design, engineering and construction teams that support both divisions. Meanwhile, the rest of the companies have functional organizational structure. Trainings were given to all relevant staff once the technologies were adopted. Although the owner did mention about some difficulties among staffs to accept the technologies, it has not hamper their usage as their core works revolved around them. Sufficient training and skilled staffs had also speed up the adjustment period.

Example;

At first very difficult...so many people did not know (how to use the system), but if I use SAP or other software, it will be the same problem, so we have to give training"

The culture of all companies except Company B seemed to be dictated by the owner especially in terms of 'green technology' mindset and innovative culture. For example, staffs need to promote the use of green materials for cabins to clients although the clients might not require it. Quality was seen as a strategy competitive advantage and Company A was in the process of being accredited for ISO 9000 while Company C and D were certified not only by ISO 9000 but also 14000 . The organizational culture of these companies was strong and innovative in nature. For example, owner-manager of Company $\mathrm{C}$ believed that 'education matters less if you are willing to learn'. This principle rings true as one of his R\&D team member had only SPM level qualification.

Training and development is seen as key feature requirement. As technologies keep changing, the knowledge acquired need to be fluid and dynamic. In Company F, internal training was seen as compulsory and a tool for knowledge sharing; 
Learning is important especially in the production. If there is no learning, we will be left behind. Knowledge which is known to only certain people is not worthwhile, everybody needs to know. If there is new technology, the Engineering General Manager and production will go to the course. Once they come back, they will call the concerned department and share the knowledge.

Employees' benefits and welfare seemed to be considered as the company's most important asset. All companies provided competitive salary and bonus and other fringe benefits to reduce talent turnover. Despite high expectations by the owner, and the demanding jobs given, the employee turnover was low. The good employees' benefits and welfare practices were seen as resulted from the SMEs' owner-managers' most important values and beliefs. As remarked from Company E 'pasal dia orangnya macam tu' while in Company F 'it was MD ideas'. For examples'

Our welfare is very-very good. You see, we give annual dinner, employee of the month, every month we select the best employee, give 50 dollar, we have seven departments so each department select one best employees. By year-end, we have employee of the year. They will get 1000 to 2000 dollars. Then, we have bonus also. We have increment every year. We have a lot of allowances, shift allowance, attendance allowance, and transport allowance.... we also provide KFC dinner to workers, maybe two or three months once.

In Company E, providing a fair and attractive bonus package was seen as an important retention strategy;

The bonus is the key retaining factor among employees. Compared to other company in this area, this company offers the highest bonus. Many companies give red packets but here, all employees are equal and fair bonuses were given based on their performance and length of service.

Furthermore, in principle, bonus received by employees would never be less than previous years despite being performance-linked. She explained;

Bonus and increment is determined by your work performance, but never less than previous years.

In terms of salary payment, Company E's SME's owner-manager was very concern about timely payment of salary. He felt that on time salary payment is the basic of good management;

He is very particular with payday. Salary must be paid on the $1^{\text {st }}$ day of the month. He does not want the employees to anxiously wait for their salary and this will affect production. Since 20-30 years ago, the boss is still very particular about this matter.

Most jobs were structured around teams. As such, cross-functional teams were common across these companies. The use of technology was enhanced as transfer of technology know-how was more effective in teams.

\subsubsection{External Factors}

All these companies were driven by customers' requirements and market trend. They believe in noble business strategies that utilize current technologies to capture the market segment. Customer's requirements and market demand remain main drivers for technology adoption. For example, Company A adopted the engineering simulation software to meet the stringent requirement of oil and gas industry. Company A remained a leading supplier of specialized cabin in the market due to its manufacturing capabilities and 'green technology' -based products;

(We) meet schedule, and always come out with new design and product example....use green environment material, environmental friendly, innovative in design, cabin ni kalau pandai design boleh buat cam hotel, di oversea dah ada portable house using cabin konsep, di Malaysia belum ada value added things ni...we different from others then we are not fighting with other people in terms of price cause our sector we target different we are looking forward to adapt BMA material

In addition, in Company $\mathrm{C}$;

When we have demand, we will adopt technologies(to fulfill the demand)

We never say no to the customers, if the customer wants something, the boss will say give me some times. And he will find the ways to fulfill the customer requirements.

Similarly, company $\mathrm{C}$ and D regarded themselves as pioneers in green recycled products. For example, Company D was the sole manufacturer of degradable plastic bag in Asian Pasific Region while Company $\mathrm{C}$ was the sole manufacture of recycled colored plastic resin. Their businesses were products of green market trend. Company $\mathrm{C}$ regarded competitors as strategic alliances while Company $\mathrm{B}$ and $\mathrm{C}$ regarded their competitors as catalyst for further improvements. For example in Company ;

We are one out of six in the world (that use the technology) and a leading company is Asia 
Although Company A was not reliant on the financial assistance provided by the government, it utilizes the exclusive licensing that was granted only to the Bumiputra. Company $\mathrm{C}$ was also not reliant on financing provided by the government. Company $\mathrm{B}$, however, was highly reliant on the financial assistance by the government agencies and utilizes the training and skills development provided by the government agencies. The main challenge facing by the Company B is on the bureaucracy of the government agencies. Company $\mathrm{B}$, has a very good networking with its suppliers and customers. The company uses the one-to-one interactions with its customers to explain and market synthetic bone. Although, Company B is the only supplier for the synthetic bone in Malaysia it has not dominated the market due to other substitute bones produced by other companies in Malaysia and overseas. Thus, they are trying to get certification from an international body as a marketing strategy to penetrate more potential customers. It should be noted that Company A and B had Malay owners and to certain extent, they received some benefits in terms of sole licensing or financial assistance.

Nonetheless, all of these companies rely on their capabilities to penetrate niche market segment for their products.

\section{Discussions and Conclusions}

In all cases, the characteristics of the owner-managers are significant predictor in SMEs' technology adoption in Malaysia. These include the academic qualification of the owner manager, their commitment, passion, leadership style, technology know-how, awareness of the technology which was resulted from the exposure and openness to learn of the owner-managers. The result strongly indicates that the owner-manager is the 'drive' of survival of the respective companies. The result is consistent with Chibelushi (2008), Thorpe et al., (2005), Qirim (2007) and Gray (2006) Apparently the intangible aspects such as the owner-managers' value is more essential when we discuss on the influencing factors of the owner-managers of SMEs in technology adoption.

Another interesting finding of this study is when technology alone is not enough for enhancing effectiveness and efficiency of a company. It needs to be supported with other resources such as staff with certain levels of competencies to benefit the investment in the technologies chosen. Technology cannot be treated in its isolated island. It needs to be integrated with other business functions as suggested by Khalil (2002). All companies in this study identifying the not only suitable trainings but ensure sufficient trainings were given to all their staff. This finding also substantiate the study by Acs and Audretch (1998) who asserted that smaller firms is seedbed of innovation. As evident from these cases, most companies are innovative and could speed up commercialization period up to one month only.

Organizational culture is another important component that facilitates technology adoption. Organizational culture acts 'a glue holding organization together' as organizations adopt technologies driven by external market and customer requirements. Organizational culture geared around technology can provide leverage for organizational change and are strategically linked with performance result. This evident from these cases whereby all companies agreed that their performance and productivity had improved with the adoption of technologies.

Teamwork is an important factor as the technology-based companies operates in collective strengths of their resources and not only reliant on the owners competencies. This finding is particularly interesting as teamwork has not been thoroughly investigated as enabler of technology adoption in current research. Based on the findings, strong teamwork orientation not only facilitates knowledge sharing but also a building block of cohesive organizational culture. Cross-functional departments, although distinctive in terms of functions, would collaborate on matters of great importance to the companies.

However, these companies received different forms of assistance from government agencies. Company B received not only financial assistance but also technology know-how and training. Company A, which is also considered a spin-off company, received financial assistance after it had performed quite well in the business. Other companies received assistance in terms of university-industry collaboration and also consultancy provided by the government agencies. It is important to note that most of these companies are reliant on strong R\&D initiatives either through their own R\&D works or findings from universities or research institutions. Even for Company A which is not using high technology, rely on international exposure and current research provided by his brother who worked oversea and studied green materials.

High customer orientation is another distinctive feature of these SMEs. Their adoption of technologies are driven customer requirement and market trend. They regard technologies that they use as competitive strategy to remain strong in the industry. In summary, the preliminary study of influencing characteristics in technology adoption in SMEs in Malaysia is as in figure shown below; 


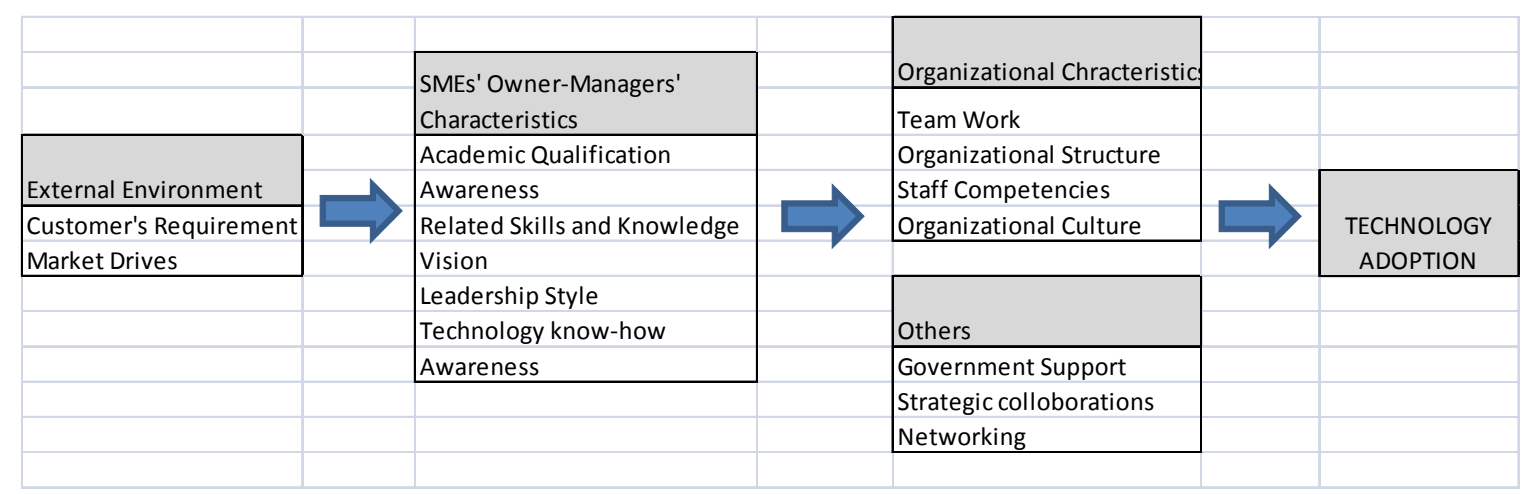

Figure 1. Influencing characteristics of technology adoption SMEs in Malaysia

This research is unique as it proposed the model based on the analysis of qualitative data. Majority of previous literature concentrated on certain type of technology such as information technology, advanced technology and manufacturing technologies. However, in this study the authors expand the concepts of technology adoption which is not based on certain technology but widen the understanding of technology which is as means to enhance the effectiveness and efficiency of operations in organizations.

Future work should be focusing on expanding factors identified in the preliminary study to provide a resource to academics and managers in industry. Research is planned to explore further the theoretical and practical aspects of influencing factors of technology adoption among SMEs in Malaysia. Thus, improved understanding of technology adoption concepts through the integration of technology-organization-people is achieved.

\section{References}

Abdullah, M. A. (2002). An Overview of the Macroeconomic Contribution of SMEs in Malaysia. In Harvie, C., \& Lee, B. C. (Eds.), The Role of SMEs in National Economies in East Asia. Studies of Small and Medium Enterprises in East Asia Series.

Abdullah, N. H., \& Shamsuddin, A. (2010). Technology Adoption among SMEs in Malaysia: Development Assessment Process. Portland International Conference on Management of Engineering \& Technology. USA. http://dx.doi.org/ 10.1109/2009.5261819

Acs, Z. J., Morck, R., Shaver, J. M., \& Yeung, B. (2003). The Internationalization of Small and Medium-Sized Enterprises: A Policy Perspective. In Audretch, D. V. (Ed.), SMEs in the Age of Globalization.

Acs, Z., \& Audretch, D. B. (1998). Innovation, market structure and firm size. Review of Economics and Statistics, 69, 567-574.

Alam, S., \& Ahsan, M. N. (2007). ICT Adoption in Malaysia SMEs from Services Sectors: Preliminary Findings. Journal of Internet Banking and Commerce, 12(3). Sage Publications Ltd.

Alam, S., Khatibi, A., Ahmad, M., \& Ismail, H. (2007). factors Affecting e-commerce Adoption in the Electronic Manufacturing Companies in Malaysia. International Journal of Commerce and Management, 17(12), 125-139. http://dx.doi.org/10.1108/105692107110776503

Beatty, R. C., Shim, J. P., \& Jones, M. C. (2001). Factors Influencing Corporate Web Site Adoption: A Time-Based Assessment. Information \& Management, 38, 337-354. http://dx.doi.org/10.1016/S0378-7206(00)00064-1

Bollard, A. (1984). A Handbook of Small-scale Business Opportunities. London: Intermediate Technology Publications.

Brown, S., Massey, A., Montoya-Weiss, M., \& Burkman, J. R. (2002). Do I Really have to? User Acceptance of Mandated Technology. European Journal of Information Systems, 11(4), 283-295. http://dx.doi.org/10.1057/palgrave.ejis.3000438

Chau, P. Y., \& Tam, K. Y. (1997). Factors Affecting the Adoption of Open Systems: An Exploratory Study. MIS Quarterly, 24(1), 1-24. http://dx.doi.org/10.2307/249740

Chibelushi, C. (2008). Learning the Hard Way? Issues in the Adoption of New Technology in Small Technology Oriented Firms. Journal of Education and Training, 50, 725-736. http://dx.doi.org/10.1108/00400910810917091 
Davis, F. D. (1989). Perceived Usefulness, Perceived Ease of Use, and User Acceptance of Information technology. MIS Quarterly, 13(3), 319-339. http://dx.doi.org/10.2307/249008

Dong, L. (2001). Modelling Top Management Influence on ES Implementation. Business Process Management, 7, 243-250. http://dx.doi.org/10.1108/14637150110392737

Economic Report 2005/2006. Ministry of Finance. Kuala Lumpur: PNMB

Eight Malaysian Plan. (2001-2005). Kuala Lumpur: Percetakan Nasional Malaysia Berhad.

Featherman, M., \& Fuller, M. (2003). Applying TAM to E-services Adoption: The Moderating Role of Perceived Risk. Proceedings of the 36th Hawaii International Conference on System Science. http://dx.doi.org/10.1109/HICSS.2003.117443

Fishbein, M., \& Ajzen, I. (1975). Belief, Attitudes, Intention, and Behavior: An Introduction to Theory and Research. Addison-Wesley Pub.

Grandon, E. E., \& Pearson, J. M. (2004). Electronic Commerce Adoption: An Empirical Study of Small and Medium US Businesses. Information \& Management, 42(1), 197-216. http://dx.doi.org/10.1016/j.im.2003.12.010

Gray, C. (2006). Absortive Capacity, Knowledge Management and Innovative in Entrepreneurial Small Firms. International Journal of Entrepreneurial Behaviour \& Research, 12(6), 345-360. http://dx.doi.org/10.1108/13552550610710144

Hall, A. A. M. (1981). Malay Entrepreneurship Problems in Development: A Comparative Empirical Analysis. Kuala Lumpur: Unit Penyelidikan Sosio Ekonomi Jabatan Perdana Menteri.

Hamid, A. B. A., Othman, M. H. M., Selemat, R., \& Norhamimah. (2003). An Encouraging Factors for Entrepreneur in Franchising: A Malaysia Experience. Small Enterprise Association of Australia and New Zealand 16th Annual Conference, Ballarat.

Harvie, C. (2002). Economic Transition: What can be Learned From China's Experience. International Journal of Social Economics, 26, 1091-1123. http://dx.doi.org/10.1108/03068299910245840

Hashim, J. (2007). Information Communication technology (ICT) Adoption among SME Owners in Malaysia. International Journal of Business Information, 2(2), 221-239.

Hashim, M. K., \& Wafa, S. A. (2002). Small and Medium-sized Enterprises in Malaysia: Developmental Issues. Selangor: Prentice Hall Pearson.

Iacovou, C., Benbasat, I., \& Dexter, A. (1995). Electronic Data Interchange and Small Organizations: Adoption and Impact of Technology. MIS Quaterly, 19(4), 465-485. http://dx.doi.org/10.2307/249629

Iqbaria, M., Zinatell, N., Cragg, P., \& Cavaya, A. L. (1997). Personal Computing Acceptance Factors in Small Firms: A Structural Equation Model. MIS Quarterly, 21(3), 279-302. http://dx.doi.org/10.2307/249498

Jomo, K. S., \& Felker, G. (Eds.) (1999). Technology, Competitiveness and the State: Malaysia's Industrial Technology Policies. London: Routledge. http://dx.doi.org/10.4324/9780203031179

Khalil, T. (2002). Management of Technology: The Key to Competitiveness and Wealth Creation. Singapore: Mc Graw Hill.

Kuan, K. K., \& Chau, P. Y. (2001). A Perception-based Model for EDI Adoption in Small Businesss Using a Technology-Organization-Environment Framework. Information and Management, 38, 507-521.

La Rovere, R. L. (1998). Diffusion of Information Technologies and Changes in Telecommunications Sector: The Case of Brizilian Small and Medium-sized Enterprises. Information Technology and People, 11(3), 194-206. http://dx.doi.org/10.1108/09593849810227995

Lee, Y., Kozar, K. A., \& Larsen, K. R. (2003). Technology Acceptance Model: Past, Present and Future. Communications of the Association for Information Systems, 12(50), 752-780.

Malaysia, First Malaysia Plan 1966-1970. Kuala Lumpur. National Printing Department.

Malaysia, Second Malaysia Plan 1971-1975. Kuala Lumpur. National Printing Department.

Malaysia, Third Malaysia Plan 1976-1980. Kuala Lumpur. Government Press.

MASTIC Report. Retreived from http.www.mastic.org.my 
Nikas, A., Poulymenakou, A., \& Kriaris, P. (2007). Investigating Antecedents and Drivers Affecting the Adoption of Collaboration Technologies in the Construction Industry. Automation in Construction, 16(5), 632-641. http://dx.doi.org/10.1016/j.autcon.2006.10.003

Ninth Malaysia Plan. (2006-2010). Percetakan Nasional Malaysia Berhad, Kuala Lumpur.

Normah Mohd Aris. (2006). SMEs: Building Block of Economic Growth. National Statistics Conferences. Malaysia.

Nystrom, P. C., Ramamurthy, K., \& Wilson, A. L. (2002). Organizational Context, Climate and Innovativeness: Adoption of Imaging Technology. Journal of Engineering Technology Management, 19, 221-247. http://dx.doi.org/10.1016/S0923-4748(02)00019-X

Petroni, A., \& Rizzi, A. (2001). Antecendents of MRP Adoption in Small and Medium-sized Firms. Benchmarking: An Integrated Journal, 8(2), 144-156. http://dx.doi.org/10.1108/14635770110389852

Premkumar, G., \& Roberts, M. (1999). Adoption of New Information Technologies in Rural Small Businesses. Omega, 26(6), 467-484.

Qi, J., Shu, H., \& Zeng, J. (2006). An Extended TAM for Subcribers' Adoption of Mobile Data Services Provided by Wireless Communication Systems Research and Practical Issues of Enterprise Information Systems. IFIP International Federation for Information Processing, 429-430. http://dx.doi.org/10.1007/0-387-4456-X_43

Qirim, N. A. (2007). The Adoptiobn of e-Commerce Communications and Applications technologies in Small Businesses in New Zealand. Electronic Commerce Research and Applications, 6(4), 462-473.

Ramayah, T., Mohamad, O., Omar, A., \& Malliga, M. (2009). Technology Adoption among SMEs: A Research Agenda. World Academy of Science, Engineering and Technology, 53.

Rogers, E. M. (1995). Diffusions of Innovations (4th ed.). New York: Free Press.

Saskatchewan National Research Council. (1988). Technology Adoption by Small and Medium Industries in Malaysia. Universiti Putra Malaysia and University of Saskatchewan.

Schein, E. (1991). The Role of the Founder in Creating Organizational Culture. In J. J. Kao (Ed.), The Entrepreneurial Organization. New Jersey: Prentice-Hall Inc.

Seventh Malaysia Plan. (1996-2000). Percetakan Nasional Malaysia Berhad, Kuala Lumpur.

Small and Medium Industries Development Corporation (SMIDEC). (2007). SME Performance 2007.

Taalika, S. (2004). Assessing the Managerial Influence as a Facilitating Factor in Innovation Adoption Process. Proceedings of the IAMOT Conference. Washington, D.C.

Tan S. P., \& Lisa. (2004). Small Firms: Definition, Growth Factors and their Roles in Economic Development. LT Software Application Sdn. Bhd. International Journal of Information Management, 26(6), 428-441.

The World Bank Report. (1997). Malaysia Enterprise Training, Technology and Productivity. Washington: United Nation Development Programme and Government of Malaysia.

Thong, J., \& Yap, C. S. (1995). CEO Characteristics, Organizational Characteristics and Information Technology Adoption in Small Business. Omega, 23(4), 429-442. http://dx.doi.org/10.1016/0305-0483(95)00017-I

Thorpe, R., Holt, R., Macpherson, A., \& Pittaway, L. (2005). Using Knowledge within Small and Medium-sized Firms: A Systematic Review of the Evidence. International Journal of Management Reviews, 7(4), 257-281. http://dx.doi.org/10.1111/j.1468-2370.2005.00116.x

Tidd, J., \& Bessant, J. (2009). Managing Innovation: Integrating Technological, Market and Organizational Change (4th ed.). West Sussex: John Wiley and Son Ltd.

Tornatzky, L. G., \& Fleischer, M. (1990). The Process of Technological Innovation. Lexington, MA: Lexington Book.

Tung, L. L., \& Rieck, O. (2005). Adoption of Electronic Government Services among Business Organizations in Singapore. The Journal of Strategic Information Systems, 14(4), 417-440. http://dx.doi.org/10.1016/j.jsis.2005.06.001 
Venkatesh, V. (2000). Determinants of Perceived Ease of Use: Integrating Control, Intrinsic Motivation, and Emotion into the Technology Acceptance Model. Information Systems Research, 11(4), 342-365. http://dx.doi.org/10.1287/isre.11.4.342.11872

Venkatesh, V., \& Davis, F. D. (1996). A Model of the Antecedents of Perceived Ease of Use: Development and Test. Decision Sciences, 27(3), 451-481. http://dx.doi.org/10.1111/j.1540-5915.1996.tb01822.x

Venkatesh, V., \& Morris, M. G. (2000). Why Don't Men Ever Stop to Ask for Directions? Gender, Social Influence, and Their Role in Technology Acceptance and Usage Behavior. MIS Quarterly, 24(1), 115-139. http://dx.doi.org/10.2307/3250981

Wang, Y., \& Qualls, W. (2007). Towards the Theoretical Model of Technology Adoption in Hospitality Organizations. Hospitality Management, 26(3), 560-573. http://dx.doi.org/10.1016/j.ijhm.2006.03.008

Wu, F., Yeniyurt, S., Kim, D., \& Cavusgil, S. T. (2006). The impact of information technology on supply chain capabilities and firm performance: A resource-based view. Industrial Marketing Management, 35(4), 493-504. http://dx.doi.org/10.1016/j.indmarman.2005.05.003

Yin, R. (2010). Case Study Research: Theory, Methods, Practice (4th ed.). Emerald Group Publishing. http://dx.doi.org/10.1177/1468794112442314

Zhang, C., \& Dhaliwal, J. (2009). An Investigation of Resource-based and Institutional Theoretic factors in Technology Adoption for Operations and Supply Chain Management. International Journal of Production Economics, 120(1). http://dx.doi.org/10.1016/j.ijpe.2008.07.023

\section{Copyrights}

Copyright for this article is retained by the author(s), with first publication rights granted to the journal.

This is an open-access article distributed under the terms and conditions of the Creative Commons Attribution license (http://creativecommons.org/licenses/by/3.0/). 